\title{
From Once-Dominant Minority to Historical Christian Outpost on the Southern Caspian: Azerbaijan's Orthodox Christians
}

\author{
Bruno De Cordier
}

Department of Conflict and Development Studies under the Faculty

of Political and Social Sciences of Ghent University, Campus Aula-Oude School

bruno.decordier@ugent.be

\section{Cristina Boboc}

Department of Conflict and Development Studies under the Faculty

of Political and Social Sciences, Ghent University, Campus Aula-Oude School cristina.boboc@ugent.be

\begin{abstract}
Based on field observations and an empirical survey on religion and identity that was conducted among the Slavic Orthodox population in the wider Baku area and in Ganja, this article examines the identity and social position of this community, now the country's main Christian population group. While earlier research on the nominally Christian Slavic groups in the Caspian-Central Asian space tended to concentrate on ethnolinguistic and political issues, this research focuses on religious identification, religious practice, and the status of the Orthodox Church. Numbering just 1.5 percent of the population, the Orthodox Christian community in Azerbaijan is nearing extinction due to its aging membership. Nonetheless, Orthodox Christianity will keep a presence in the country and its society, although it could attract a more heterogeneous following.
\end{abstract}

\section{Keywords}

Azerbaijan - Christian minorities in Islamic societies - Orthodox Christianity - Slavic minorities in Soviet successor states - social identity - Southern Caucasus-Caspian 
Reactionaries and Marxists will both live as uncomfortably in future society. But whereas the Marxists will look upon it with the eyes of a dumbfounded parent, we will regard it with the irony of an outsider.

-NICOLAS GOMEZ DAVILA (1913-1994)

Predominantly Slavic Orthodox, the Christian community comprises a small minority in contemporary Azerbaijan. Both their actual presence and their historical importance as a dominant minority in the country, however, are visible in the form of active Orthodox churches and parishes typically situated close to railway stations, former sites of military barracks, in specific rural areas, and in Baku's nineteenth-century European quarter. All of these locations reflect well the historical circumstances in which an Orthodox presence was established in this part of the southern Caspian. During the 1990s, researchers and policymakers alike expressed interest in the position and predicament of nominally Christian Slavic groups in the non-Slavic Soviet successor states. The focus, however, was clearly on ethnolinguistic and political issues more than religious doctrine. Furthermore, interest in the religious dynamics of the Caspian-Central Asian region has long tended to focus on Islam rather than on Christianity, with an exception perhaps for the new Protestant churches and movements.

This article examines the present social and identity characteristics of Azerbaijan's Orthodox Christians, and the role and place of religion in safeguarding their minority identity and social cohesion since 1991, when Azerbaijan, a country whose majority population traditionally identifies with Shia and Sunni Islam, became independent. According to Charles Wagley and Marvin Harris, several characteristics are prevalent among minorities. For example, they usually have a subordinate position within societies. The members of the group share visible traits or characteristics that differentiate them from other groups. The minority group is a self-conscious social unit. Membership in this unit is usually determined by genealogy. And, finally, members tend to marry within the self-group. ${ }^{1}$

1 Bernard Voutat and René Knuesel, "La question des minorités. Une perspective de sociologie politique," Politix 10, no. 38 (1997): 139-140. 
What triggered our curiosity was a series of events well beyond the southern Caspian. These included the popular uprisings and coup d'états that occurred in the Arab region beginning in late 2010, and the renewed attention that these occasions drew for the presence of Copts and other Christian minorities in the majority Islamic societies there. Although the southern Caucasus and the Arab world are indeed two very different environments, a number of insights, observations, and typologies regarding Christians in Arab-Muslim societies supplement those available for the Slavic minorities in non-Slavic USSR successor states. The analysis presented here is based on these works, field observations, and a 37-question survey on religion and identity that was conducted in October and November 2015, in cooperation with an Azerbaijani research association, among 300 members of the relevant population in the wider Baku area and in Ganja. ${ }^{2}$

\section{Social Geography in Historical Perspective}

Within the official contours of Azerbaijan, Slavic Orthodox Christians form the largest Christian minority in the country alongside adherents of the Armenian Apostolic Church. Since the latter are mainly concentrated in Nagorno-Karabakh, a disputed region occupied by Armenia, they are cut off from Azerbaijan's wider society and governance structures. This means that in "rump Azerbaijan", the Orthodox now form the largest Christian minority. Often colloquially referred to as "the Russians" rather than "the Orthodox," the Slavic Orthodox, who now form around 1.5 percent of the population, basically consist of three ethnic-social categories with rather fluid boundaries. First, of course, there are citizens of Slavic ancestry proper. These comprise some 140,00o ethnic Russians - including roughly 1,500 Cossacks - Ukrainians, and Belarusians. Among all of these, a form of Orthodox Christianity is historically and at least nominally part of their ethno-cultural identity.

Second come around 3,00o Molokans, who belong to a schismatic current of Spiritual Christians (dukhovnye khristiane) to which the Dukhobors also belong. Although the members of this minority within the minority are officially

2 Rufat Garagözlu and Hikmet Hajizade conducted and coordinated the quantitative part of the survey "Social Organization and Identity among the Slavic Orthodox population in Azerbaijan" in Baku city, the wider Baku area and in Ganja. The research was funded by the Fwo Research Foundation Flanders and the Marie Curie Skłodowska-Curie CASPIAN-ITN project. Bruno De Cordier also published a brief article based on this research in the February 2016 issue of Caucasus Analytical Digest. 
considered to be Russians, their distinctive identity and a lifestyle centered around a sixteenth-century breakaway sect of Orthodox Christianity - reminiscent somehow of an Orthodox version of the Amish - and a presence in the country that predates that of most of Azerbaijan's present-day Slavic groups, make, that they are locally often seen as a group separate from the adherents of mainstream Orthodox Christianity. Third, there are the people of mixed Slavic-Azerbaijani origin who identify themselves to one or another degree with Orthodox Christianity and who are also often accounted or declare themselves to be Russian in censuses. What these three population groups have in common, is the use of Russian as their primary language.

The portion of the population actively using Russian in everyday life, or as the language of inter-ethnic communication, is actually much larger that the Slavic minority, though. With officially 21.4 and 23.7 percent, respectively, fluency and use of Russian is quite high among certain ethnic minorities like the Georgians and the Lezgins. Like the Slavic peoples, the Georgians are part of the country's traditional Christian minority, while the Lezgins, a predominantly Sunni Muslim group, are concentrated in a geographic area adjacent to the Russian border and also consider the Russian language as a mean to counterweight real or feared assimilation in the Azerbaijani majority culture. Russian speakers (russkoyazychnye) also include many intergenerational-urban Azerbaijani who are engaged in intellectual professions and who received most of their education in Russian. So, although Orthodoxy also has adherents among non-Slavic and métis (people of mixed-race, usually Slavic and Turkic) groups, the Slavic population and Russian speakers form, by far, its main ethnodemographic or physical and ethnic base. ${ }^{3}$

Few members of the majority Azerbaijani population would describe themselves as Orthodox Christians. As such, the Orthodox minority in the country differs from Arab Coptic Christians, for instance, in the sense that the latter ethnolinguistically do belong to the indigenous Arab majority and at once differ from it by confession. Today, the largest portion of the country's

3 This near-convergence of a religious adherents grouping and a non-indigenous ethnic-racial population is quite similar to the predominantly French Pieds-Noirs following of Roman Catholicism that existed in Algeria until 1959-1962. Around 1959, people of Roman Catholic background or tradition formed 7-9 percent of a population of some 11.2 million. The group has almost disappeared, however, with the departure, after independence in 1962, of the country's Franco-European population, a large part of which, like part of the Slavs in Azerbaijan, had lived in the country for generations. Today, Roman Catholicism has a symbolic presence in Algeria, with four dioceses and some monasteries most often staffed by clergy born outside of the country. They see themselves as custodians of a Christian presence in the area that dates back to late Antiquity. 
Orthodox Slavs, roughly 90 percent, live in Baku or within a radius of 30 kilometers around the city. Beyond that, there are much smaller communities in the cities of Ganja, Mingäçevir, and Lenkoran on the southern Caspian coast. In rural Azerbaijan, there are small communities in Ismaili district, specifically in Ivanovka where the majority of the Molokans live, in Xaçmaz, where there is a residual concentration of people of Belarusian and Cossack origin, and also in some rural districts along the Azerbaijani-Georgian border. Slavs and Orthodox do not form a majority in any district. ${ }^{4}$ Table 1 offers a historical overview of the shifting demographic share of Slavs (Russians, Ukrainians, and Belarusians) in Azerbaijan between 1897 and the most recent national population census in 2009. As one can see, this minority's present population share is a fraction of previous levels.

TABLE 1 The evolution of the absolute number and relative population share of Slavs in Azerbaijan between 1897 and 2009

\begin{tabular}{lccccccccc}
\hline & $1897^{*}$ & $1926^{* *}$ & 1939 & 1959 & 1970 & 1979 & 1989 & 1999 & 2009 \\
\hline $\begin{array}{l}\text { Total number } \\
\text { (persons) }\end{array}$ & $95,73^{6}$ & 241,653 & 553,433 & 531,344 & 544,148 & 506,439 & 432,482 & 170,700 & 143,800 \\
$\begin{array}{l}\text { Slavic-Orthodox } \\
\text { population share }\end{array}$ & 5.6 & 10.6 & 17.3 & 14.3 & 10.6 & 8.4 & 6.2 & 2.1 & 1.6 \\
percent & & & & & & & & & \\
\end{tabular}

* Figures for the Governorates of Baku and Elisabetpol, whose joint territory more or less encompassed that of present-day Azerbaijan. The figures comprise what was then called Greater Russians, Little Russians and Belarusians.

** Situation for the Azerbaijani ssR of the Transcaucasian Soviet Socialist Federative Republic. Sources: Data for 1897: “Pervaya vseobshchaya perepis' naseleniya Rossiyskoy Imperii $1897 \mathrm{~g}$. Raspredelenie naseleniya po rodnomy yazyku i uezdam Rossiyskoy Imperii krome guberniy Evropeyskoy Rossii," Demoskop, http://www.demoscope.ru; Data for 1926-1989: "Vsesoyuznaya perepis' naseleniya 1926 goda. Natsional'nyy sostav naseleniya po respublikam sssR" and “Vsesoyuznaya perepis' naseleniya 1939 (1959, 1970, 1979, 1989) goda. Natsional'nyy sostav naseleniya po respublikam sssR," Demoskop, http://www.demoscope.ru; Data for 1999 and 2009: State Statistical Committee of Azerbaijan, data spreadsheets of the population censuses of 1999 and 2009, http://www.stat.gov.az.

4 There are no neighborhoods or townships in Baku and Ganja with a specific concentration of Orthodox Slavs either, like the Greek Orthodox neighborhoods and suburbs in Beirut and especially Tripoli in Lebanon, for example. 
French geographer André Bourgey distinguishes three types of Christian minorities in majority Islamic countries. ${ }^{5}$ First, there are what he calls the traditional or historical minorities whose presence mostly predates the coming of Islam. They are usually remnants of a once much larger - if not majority Christian presence in the given area. Examples include the Copts in Egypt and Azerbaijan's tiny Udi-Albanian community. ${ }^{6}$ Second come Christians whose presence is the result of recent labor migration. A typical example are the sizeable numbers of Roman Catholic Filipinos in the high-income countries of the Persian-Arab Gulf. And third, and most relevant here, are Christian minorities whose presence is the outcome of major political shifts that took place during the last two centuries, like population movements and displacement, the annexation and integration of the given areas and societies in a greater space, and the emergence of nation-states and the border delineation that goes with it. ${ }^{7}$ A clear example in this category is the Armenian community of Aleppo, much of which arrived after 1915 as expellees and deportees from the core areas of the then moribund Ottoman empire.

This category is also where Azerbaijan's Orthodox minority fits, for its presence is the outcome of major political shifts. A permanent Orthodox Slav presence in contemporary Azerbaijan goes back as far as the $1795^{-1826}$ period, when groups of Cossacks settled along the southern Caspian coast. In 1830, religious dissidents like the Molokans and Doukhobors, facing increasing pressure and persecution in Russia proper, migrated to the Mugan steppe or were resettled there. Starting around 186o, an increasing number of Slavic peasant communities came into being in what were then the Baku and Elisabetpol Governorates. ${ }^{8}$ The industrialization drive that came with Baku's first oil boom

5 André Bourgey, "Les minorités et l'organisation de l'espace de l'Orient arabe," Cahiers de la Méditerrannée 41, no. 1 (1990): 186-196.

6 Founded in 488, the Apostolic Church of Caucasian Albania, which has some 3,80o adherents, primarily among the Ibero-Caucasian Udi minority in Gabala, is the oldest surviving and officially recognized church in present-day Azerbaijan. See Sara Kasumova, "O khristianstve v srednevekovom Azerbaydzhane," Kavkaz i globalizatsiya—zhurnal sotsial'no-politicheskikh i ekonomicheskikh issledovaniy 4, no. 3-4 (2010): 176-183. Caucasian Albania is a historical region that existed during Antiquity and the early Middle Ages on the territory of what is now northwestern Azerbaijan and southern Dagestan, and has no relation with Albania in the Balkans.

7 A similar category, minorities whose presence results from and invokes a country's past belonging to a larger political space, is also identified in Marek Koter, "Classification géographique des minorités ethniques," Espaces, populations, sociétés 3 (1994): 293.

8 Sudaba Zeynalova, "Etnodemograficheskie izmeneniya na Kavkaze: formirovanie evropeyskikh obshchin (XIX—nachalo xx vv.)," Kavkaz i globalizatsiya—zhurnal sotsial'nopoliticheskikh i ekonomicheskikh issledovaniy 3, no. 4 (2009): 108-121; Zahida Alizade, 
(ca. 1870-1910) and with the economic modernization and social transformation that took place in the Azerbaijani SSR (ca. 1930-1960) created further channels of Slavic settlement in the country up to a zenith of more than 17 percent of the population by the year 1939. This gradually decreased due to higher birth rates among the Azerbaijani majority and due to moratoriums on resettlement after 1959 .

However, the most dramatic population plunge occurred in the 1988-1993 period. Between early 1988 and autumn 1993, the Azerbaijani ssR and, after late 1991, newly independent Azerbaijan were affected by communal unrest between Azerbaijani and ethnic Armenians in and around Baku and the 1990 Black January crackdown, the Nagorno-Karabakh War, a secession attempt in the southern region of Talysh-Mugan, and finally a factional coup in Ganja. The Orthodox Slavs, as a dominant minority in the republic, were not specifically targeted during the turmoil. Nonetheless, the disintegration of a USSR with which they strongly identified (and, in part, still do so up to this day), the perspective of long-term chaos, and the rapid decline of the industries and social institutions in which they were economically active, were perceived to be an existential threat. ${ }^{9}$ The subsequent mass exodus now seems to be more or less stabilized. In our survey, $5^{8}$ percent of the respondents declared that they did not to want to leave Azerbaijan at all, while 3.7 percent decided to do so permanently, and 11.7 percent were uncertain.

The culturally Orthodox community that remains today has a number of identifiable social characteristics. First, although there are officially no separate population pyramids for minorities in Azerbaijan, observations and interaction with the community under examination as well as local academic sources suggest that, due to both the emigration of a sizeable part of its younger strata after 1988-1993 and smaller families than those among Azerbaijan's Muslim or at least culturally Muslim majority, perhaps up to two-thirds of this community is over 40 years of age. Slightly over 28 percent in our research group declared themselves to be pensioners, which is more than double the national average. ${ }^{10} \mathrm{In}$ turn, this top-heavy age structure partly explains the second characteristic, namely the disproportional number of women as compared to the national population.

"Natsional'no-kolonial'naya politika tsarskogo pravitel'stva na tsentral'nom Kavkaze," Kavkaz i globalizatsiya-zhurnal sotsial'no-politicheskikh i ekonomicheskikh issledovaniy 1, no. 5 (2007): 161-170.

9 Garik Galstyan, "Les minorités russes dans le Sud-Caucase: une diaspora en voie d'extinction," Le Courrier des Pays de l'Est 1043 (2004): 30-32.

10 "Azerbaijan's Demographic Change: Implications for Social Policy and Poverty," Washington, DC, World Bank, Human Development Sector Unit, South Caucasus Country Department, No. 63155-AZ (2011): 17 . 
Here again, observation and interaction, as well as some literature sources, suggest that up to two-thirds of the Orthodox Slav population in Azerbaijan is female, which is in sharp contrast to the national average, which shows a slight surplus of men. ${ }^{11}$ Other explanatory factors include, first, the higher longevity among women and, second, the number of women of Slav origin who came to Azerbaijan or stayed there after 1988-1993 because of a marriage, often concluded during the latter ussR era, with an Azerbaijani husband. Among our respondents, 23.3 percent declared themselves to belong to this category. As a matter of fact, both of these social characteristics of the Orthodox community were quite visible when we observed how the audience of liturgies and the active parishioners in Baku and Xaçmaz were overwhelmingly female and over $5{ }^{0 .}{ }^{12}$ In terms of household size, 28 percent declared their household to consist of two people or less, 57 percent of three to four persons, and 15 percent of five or more. This is far smaller than the national average and below the household sizes of the Muslim Azerbaijani majority, where the share of households of two people or less consists of 7.6 percent, of three to four persons of 10.3 percent, and those of five or more of 44.9 percent. $^{13}$

Third, in terms of highest education level achieved, 41.7 percent declared to have completed secondary education, and in Ganja this was the highest education level completed among 62 percent of the respondents. As for higher education, $5^{6}$ percent declared to have a professional college or university degree, with a particularly high portion in Baku city, where nearly two-thirds of the respondents had completed this level. At 36 percent, Ganja has the lowest share of Orthodox people with higher education among the urban localities surveyed. This is primarily because smaller cities have been more affected by emigration, both to abroad and to Baku, of their more educated population segments since 1988-1991. And fourth, when asked to assess their overall standard of living, 6 percent of the respondents declared that they live in extreme poverty, 11 percent are (rather) wealthy, while over three-quarters characterized their situation as "acceptable" or sufficient but nonetheless precarious. Unlike certain countries and societies where religious minorities are concentrated among the business elites, the Orthodox in Azerbaijan are nearly absent

11 Sivilia Serrano, "Les Russes du Caucase du Sud: du malheur d'avoir une empire (et de le perdre)," Revue d'études comparatives Est-Ouest 39, no. 1 (2008): 201-202. See also Christophe Z. Guilmoto, "La masculinisation des naissances. État des lieux et des connaissances," Population 70, no. 2 (2015): 217.

12 Observations at different Orthodox parishes and churches in Baku and Xaçmaz, October 20-26, 2015 .

13 "Azerbaijan living Conditions Assessment Report," Washington, DC, World Bank, Human Development Sector Unit, Europe and Central Asia Region, Report No. 52801-AZ (2010): 50. 


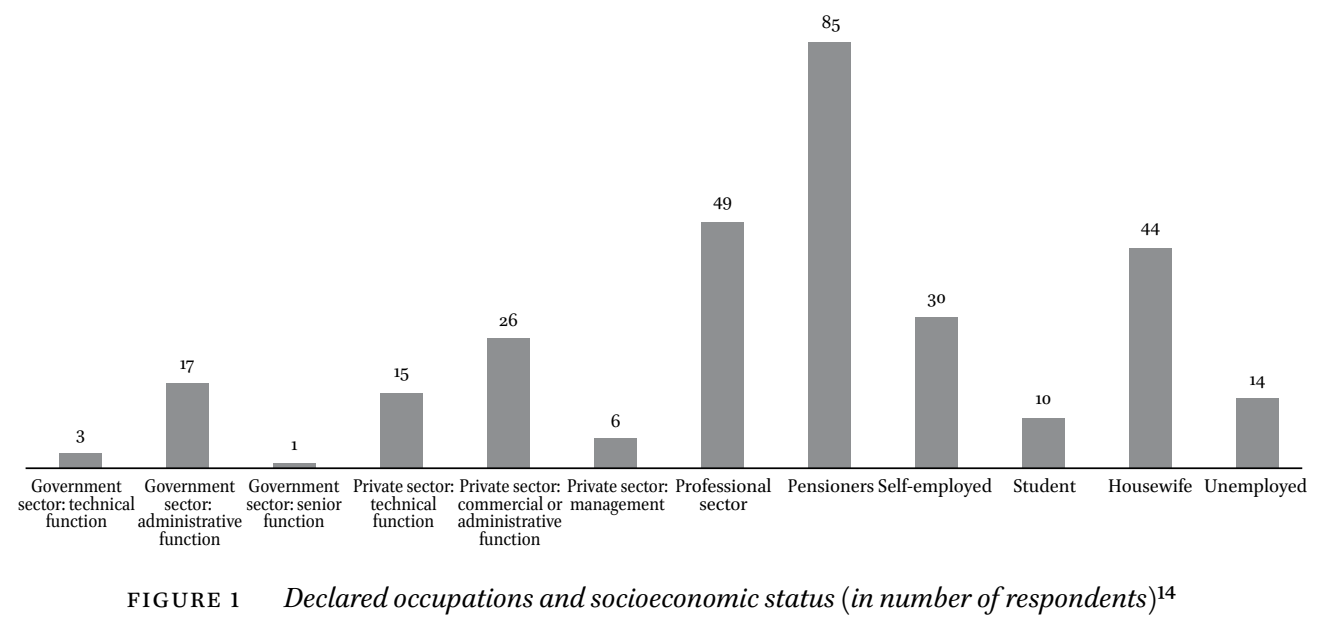

from the country's financial oligarchy because they do not have access to the necessary patronage networks.

As Figure 1 shows, in terms of social position and occupation, besides a disproportionally large portion of pensioners, 23.7 percent of the respondents declared themselves to be active in the private sector or self-employed, and 16.3 percent answered that they work in technical or so-called liberal professions. Russian companies and educational institutions and faculties where Russian is the language of instruction often form specific employment niches. Molokans, for their part, are predominantly active in agriculture. Some of their products have recently achieved some sort of fashionable branding status as "ecologically pure food" in Baku's supermarkets. Although some Orthodox Slavs do work for government institutions, their presence in that sphere is limited. This is due, first, to the requirement of fluency in Azerbaijani and, second and more important, because they have less support from patronage networks that are necessary to obtain positions in the state bureaucracy. ${ }^{15}$

\section{Orthodox Nation or "Ethno-Christians"?}

What place does religion have in the overall self-identification of the Orthodox in Azerbaijan? And is religious affiliation a primary and determining identity

\footnotetext{
14 All graphics were created by Bruno De Cordier in summer and autumn 2016 on the bases of the results of the survey.

15 Galstyan, "Les minorités russes dans le Sud-Caucase." For more on the formation and social geography of Azerbaijan's patronage networks, see Viatcheslav Avioutskii, "Les clans en Azerbaïdjan," Le Courrier des pays de l'Est 1063 (2007): 67-79.
} 


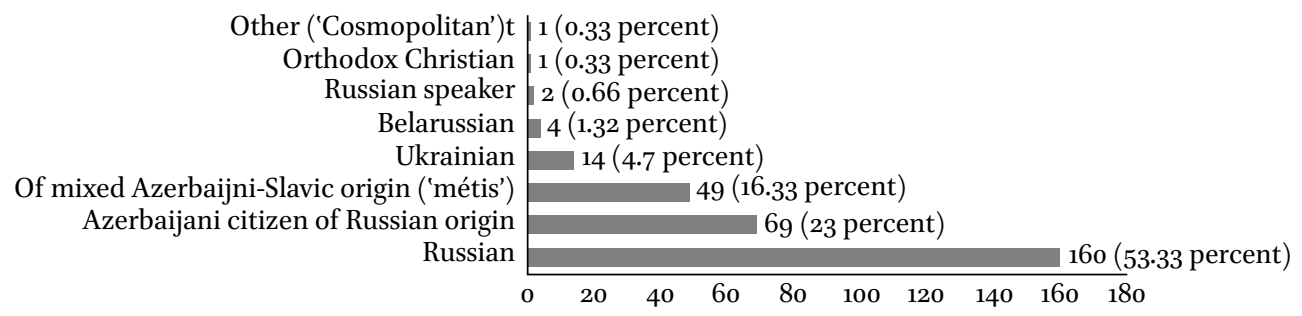

FIGURE 2 Primary self-identification ("Who or what do you consider yourself to be in the first place?") among the Slavic and culturally Orthodox population (in numbers of respondents and percent share)

factor as is the case with Christian minority groups, like the Copts in the Arab sphere, for example? As Figure 2 shows, a clear majority of the respondents consider themselves primarily to be either Russian (more than 53 percent), an Azerbaijani citizen of Russian origin (23 percent), or of mixed SlavicAzerbaijani background (a bit over 16 percent). A further six percent identified primarily as members of other Slavic ethnicities, while an insignificant share of the respondents identified themselves in terms of traditional faith, that is, as an Orthodox Christian. This suggests already that Orthodox Christianity is considered to be a component of and subordinate to a broader ethnic identity rather than a nation in its own right.

The relevance of religious adherence as a component of a wider ethnic and social identity became even clearer when the same respondents were asked to which confession, religious denomination, or church they adhered or identified themselves with, no matter whether they were practicing or not. As reported in Figure 3, only slightly more than one percent replied as belonging to or identifying with none. A similar portion cited Islam and Judaism; these respondents are probably either members of mixed Slavic-Jewish families or individual Slavic or métis converts to Shia or Sunni Islam. The vast majority, nearly 83 percent, declared that they belong to the Russian Orthodox Church of the Moscow Patriarchate, which apparently many consider to be an inalienable part of Russian ethnonational identity. ${ }^{16}$ Interestingly, about one-sixth of the population of interest, that is, not a marginal share, said that it followed other churches or confessions.

This basically includes two categories. First, there are those who belong to other Oriental churches, like Ukrainian Greek Catholics, Georgian Orthodox,

16 For insights into the functions and position of Orthodoxy and its institutions in the formation and continuation of present-day Russian ethnonational identity, see Vitaliy A. Plotkin, "Rol' pravoslaviya v formirovanii rossiyskoy natsional'noy idei," Izvestia Penzenskogo gosudarstvennogo pedagogicheskogo Universiteta 27 (2012): 895-898. 


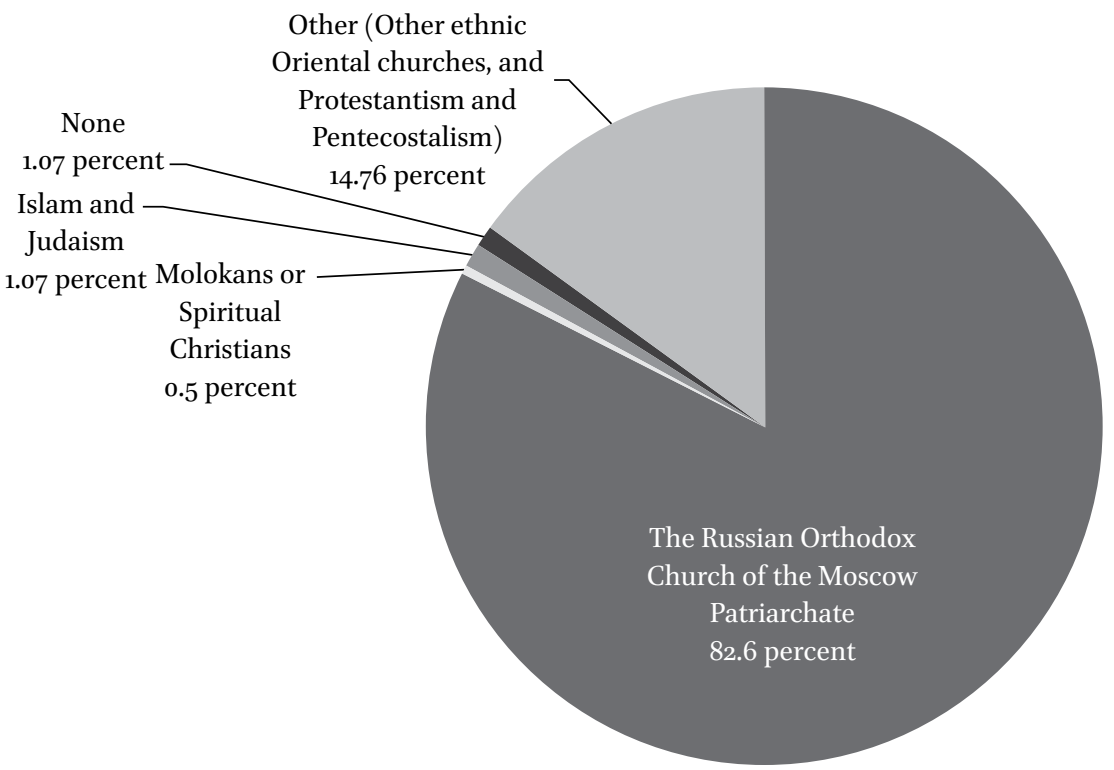

FIGURE 3 Confessional self-affliation among the Slavic and culturally Orthodox population in Azerbaijan (in percent share of respondents)

and followers of the Udi-Albanian Church, who turn to Orthodox parishes because their own denomination has no institutions, parishes, or clergy where they live. Second, and even more important, there are the adherents of the various Protestant and charismatic denominations who came to Azerbaijan during the 1990 s. $^{17}$ Due to a number of circumstances and sociological reasons, they attracted some following among the Slav minority and among métis in urban areas. Although their activity and growth seems to have stabilized if not stagnated over the past seven or eight years, the Orthodox eparchy of Baku actively monitors Protestant and Pentecostal groups. Individual priests also told us that countering the influence of non-traditional sects among the historically Orthodox population remains one of the tasks and raisons d'être of their ecclesiastical work. ${ }^{18}$

17 A few of these adhere to traditional Protestant denominations like Lutherans and Calvinism. Most however, align with Pentecostal groups, Baptists, Seventh-Day Adventists, and the Jehovah's Witnesses. The Orthodox Church as well colloquial parlance commonly refers to these groups as sektanstvo ("sects" or "sectism"). Sergo Namoradze, "Protestantizm na Kavkaze," Kavkaz i globalizatsiya-zhurnal sotsial'no-politicheskikh i ekonomicheskikh issledovaniy 2, no. 3 (2008): 178-180.

18 Interviews and conversations in Baku and Xaçmaz, October 22-25, 2015. This actually fits into a historical pattern in which the Orthodox hierarchy in Moscow and the then 


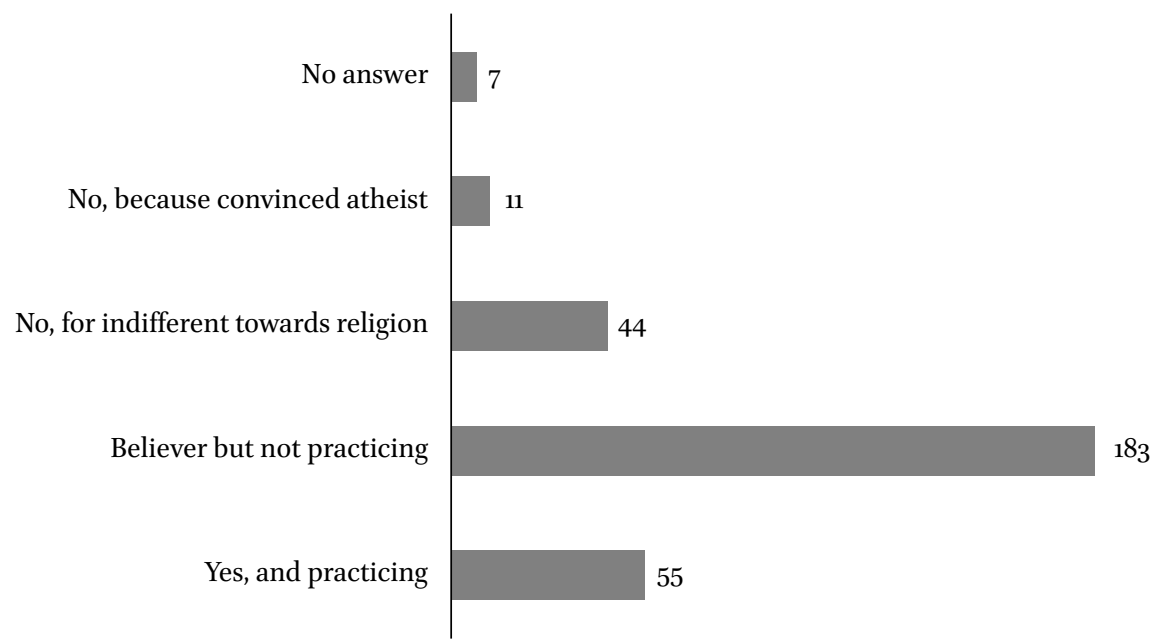

FIGURE 4 Shares of declared believers and non-believers ("Do you consider yourself to be a religious believer?") (in number of respondents)

Figure 4 goes deeper into the declared levels of religious practice and active faith. If we convert this data into percentages, then we see that 18 percent of the Orthodox or ethnically Orthodox respondents declared to be practicing believers, with the highest scores in the age brackets of 41-65 and older than 65 ; 61 percent non-practicing believers with highest among the $18-28$ years old; 14.6 percent indifferent toward religion; and 3.6 percent committed atheists with the highest level among respondents older than 65 . The latter is partly because of a stronger identification with the USSR and its official atheism among certain age and social groups. How does this compare to the national average and especially to the Muslim Azerbaijani majority population? Available empirical evidence from country-wide research conducted in autumn 2012 with a near-identical question and with similar reply categories found that 16.9 percent of the ethnic and religious majority segment considered themselves to be practicing believers, 19.7 percent believers and irregular practitioners, 61 percent non-practicing believers, and one percent committed atheists. ${ }^{19}$

Eparchy of the Transcaucasus considered the establishment of parishes among the Slavic settlers vital to counter the influence of schismatic Orthodox sects and Baptism. See Fuad Agayev, "Stroitel'stvo pravoslavnykh tserkvey v ramkakh pereselencheskoy politiki tsarisma v severnom Azerbaydzhane v kontse XIX—nachale Xx vv.," Baky Universitetinin Xäbärläri 2 (2012): 153 .

19 Hikmet Hajizade, "Nationwide Opinion Poll on the Socio-political Situation and the Problems of Religious Freedom and Religious Extremism in Azerbaijan," Baku, Center for Economic and Political Research (2012): 6. 


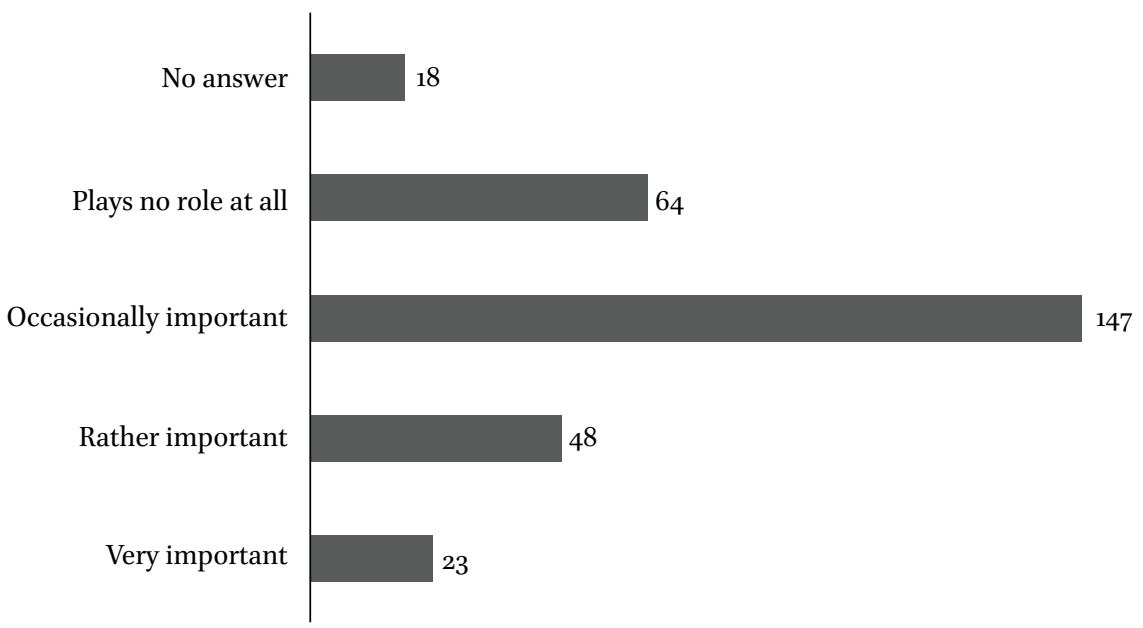

FIGURE 5 Declared importance of religion in everyday life (in number of respondents)

In the meantime, the share of the practicing believers among Sunni and Shia Azerbaijani has grown to over 20 percent of the population, especially in Baku, in some Shia areas in the far south, and in certain Sunni parts of northern Azerbaijan. Figure 5 reflects the importance bestowed on religion in everyday life. If we convert these results into percentages, then the share of Orthodox Christians in Azerbaijan who consider religion to be a very important part of everyday life is 7.7 percent; those replying "rather important," 16 percent; occasionally important, 49 percent; and no role at all, 21.3 percent. To put this into comparative perspective again with the majority population, according to a 2012 survey on Islamic religious practice that used comparable categories, 36 percent among the Muslim majority in Azerbaijan considered religion to be very important in everyday life, 38 percent somewhat important, 22 percent not too important, while 2 percent replied it had no role or importance at all. ${ }^{20}$

Finally, in terms of concrete acts of religious practice reported by the respondents, Figure 6 looks into the regularity of church attendance; the performance of prayers and religious rituals beyond the official liturgy and masses; fasting; and financial and in-kind donations to Orthodox institutions and parishes. As one can see, regularity in all these is limited to a small minority of an equivalent of 2.5 percent on average. Rather, practice in these specific fields is characterized by high volatility and irregularity, is often connected to the occasions of Orthodox holidays, varies per parish, depends on

20 "The World's Muslims: Unity and Diversity," Washington, DC, Pew Research Center-Pew Forum on Religion and Public Life (2012): 131. 
- Church attendance

- Praying and other confessional rites beyond the liturgical masses

- Religious fasting

- Donations to the church and/or to the parish

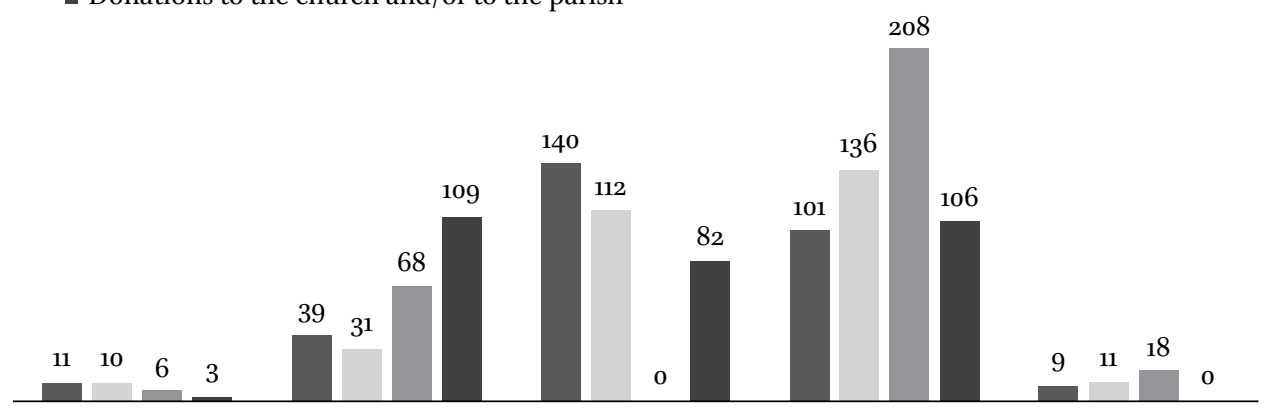

Regular Irregular

On the occasion of major Rarely or never Don't know or no answer Orthodox holidays

FIGURE 6 Declared levels of active religiosity (in number or respondents, more than one answer possible)

the availability of personal resources, and also is subject to whether and how one knows and interacts with individual priests and other representatives of the Church, their mobilizing charisma, and how these are being perceived and respected as persons.

\section{Orthodox Institutions and the Azerbaijani State}

Since 2011, after the Eparchy of Baku and the Cis-Caspian, which encompassed Azerbaijan and Dagestan, was reorganized, the Orthodox Church in the country falls under the eparchy of Baku, which is responsible for Azerbaijan only. ${ }^{21}$ Headed since 1999 by Archbishop Alexander (né Alexander Gennadievich Ishcheni), a native of Yaroslavl who served in North Ossetia before, the Orthodox church has six registered cathedrals and one chapel in the country. Four of these parishes are in Baku, one in Sumgait and one each in Ganja and Xaçmaz. A new parish was said to be planned for the southern Caspian town of Lenkoran somewhere in 2017. Inversely proportional to much of the followers' base and compared to their Roman Catholic counterparts in Western Europe - the

21 An eparchy is the Orthodox equivalent of a diocese in Roman Catholicism. Officially, the Eparchy of Baku and the Cis-Caspian (which was founded in 1998), was reorganized and split-up for practical and organizational reasons. The Azerbaijani authorities' dislike of supranational confessional entities likely was also a factor. 
Orthodox clergy, which country-wide had some 30 ordained priests at the time of research, is predominantly young, generally in their early 30 s to mid-4os. Most of the priests are Azerbaijani citizens and have been trained at theological colleges in Saratov and Stavropol, as there is no seminary in Azerbaijan itself.

Officially, the eparchy of Baku and its parishes and clergy are not funded by either the Patriarchate in Moscow or the Russian government. They reportedly depend on various kinds of private donations, elite philanthropy, in-kind support like the free or low-cost real estate, investment earnings, a favorable fiscal regime, and free utilities. ${ }^{22}$ The Orthodox Church's claimed mission is not to evangelize, but to support the existing historical community and to preserve an ancient Christian heritage in Azerbaijan, the roots of which go back to the Caucasian Albanian Church. But how strong is the level of confidence in it among the nominal and active Orthodox adherents' base? According to survey results shown in Figure 7, 9 percent of the Orthodox Slavic community seems to have a high level of confidence in the Church and its clergy. Although

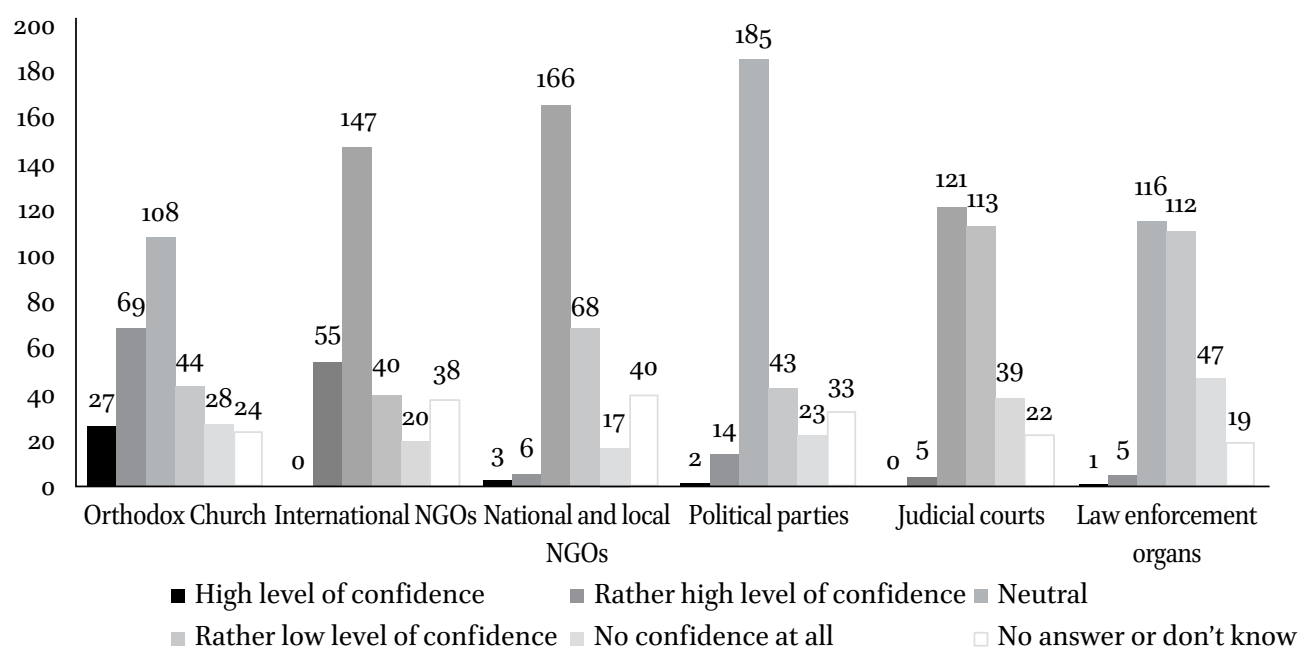

FIGURE 7 Declared confidence in the Orthodox Church and its clergy as compared to a number of other institutions (in number of respondents)

22 Interviews with Archbishop Alexander and Archpriest Mefodii Efendiev, Baku, October 23, 2015, and conversations with parish workers in Baku and Xaçmaz, October 24-25, 2015. To give an example of elite patronage of the Church, the restoration of the Holy MyrrhBearers Cathedral and its shrine of Saint Bartholomew the Apostle (the Orthodox patron saint of Baku) in the early 200os was financed by a (now-deceased) ethnic Azerbaijani, Moscow-based businessman of Shia Muslim background who was married to a Russian and was himself related to Azerbaijan's presidential family. 
in the minority, this is far superior to the shares, amounting to an average of about one percent, who ascribe a high level of trust to political parties, local as well as international non-governmental organizations, and the judicial system, for example. Regarding the clergy, 23 percent have a rather high level of trust, 36 percent have a neutral stance, and a joint 24 percent a rather low level or no trust in the clergy and the Church at all.

If varying degrees of confidence in the Church, its clergy, and lay parish workers exist and even exceed that for a number of other, secular institutions, on what are they based or where are they rooted? First, there is the real and perceived role of the Church in the preservation of the coherence and identity of the minority community. As Figure 8 shows, 15 percent of the respondents felt that the above play a large role in this process, whereas 38 percent considered this role to be rather large to medium, and 13 percent small to nonexistent. One-third, by contrast, did not know or did not answer, which reflects the rather high portion in whose lives religion plays a limited to very small role as was previously discussed around Figure 5. In either case, the fact that Orthodox Christianity is perceived to be a secondary core component of an ethnic identity and a cultural and ideological binding agent with Russia does play here, in the sense, that the Church ensures some institutionalization and visibility of its own minority group's presence in the country.

"The Church" must be understood here as the Baku eparchy. Only 5.3 percent from the interviewed members of the Orthodox minority community stated that their community received any support from the Patriarchate in

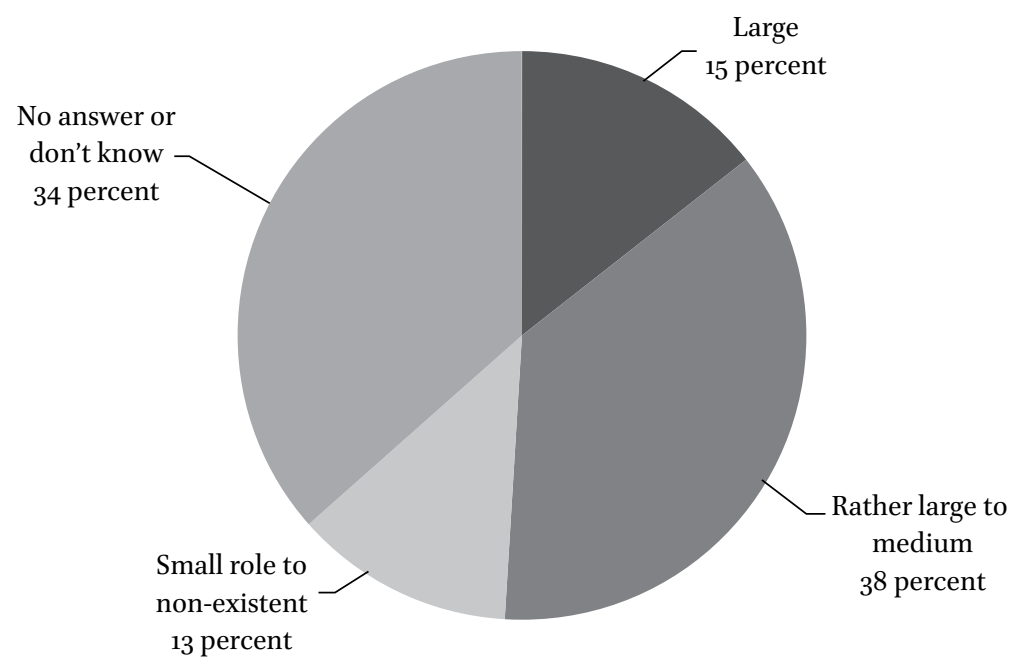

FIGURE 8 Perceived role of the Orthodox Church, its clergy, and lay parish workers in the life and preservation of coherence and identity of the community (percentage) 
Moscow itself. There is also charitable and social work conducted by, or under the auspices of, the Baku eparchy and its individual representatives. Through its social wing, the eparchy indeed declares that it conducts a number of charitable activities. Its clergy and volunteers thus organize administrative help, food packages, and the facilitation of medical support for the ill who cannot afford medical treatment, isolated pensioners, and marginalized households. Other social activities include Sunday schools, the organization of "Open Tables" on major Orthodox holidays like Easter, Trinity Sunday, Orthodox Christmas, the Epiphany, and the Old New Year, and the organization of courses in the Azerbaijani language to promote bilingualism. ${ }^{23}$

Very often a source of legitimacy and support for religious institutions and movements in number of countries and societies, the Orthodox clergy and lay workers are perceived by the respondents' base (see Figure 9), to be definitely active in the social and charitable fields by 13 percent of the respondents, and "up to a certain level" by a further 42 percent. Asked to specify in what particular activities they are so, the vast majority reported two fields, namely the organization of Orthodox religious holidays (40 percent), which do play a role in the minority's cultural life, and moral and practical assistance to pensioners and the ill (31.6 percent), which is not surprising since pensioners form a large portion of the Orthodox population in the country. Furthermore, slightly less than 10 percent mentioned assistance to the poor (food packages, soup kitchens, financial help, and so on). Fewer than 7 percent consider the Orthodox church to be active in education, a similar share to being an intermediary among themselves, the state and other ethnic-confessional communities, and two percent in relief aid, for example, after an earthquake or flood.

The Orthodox Church, in line with the official, secular Slavic community organizations and cultural centers, clearly keeps a legitimist stance vis-à-vis the state, the incumbent oligarchies and in the political realm in general, whereas among the grassroots, there is a relative acquiescence and political disengagement if not cynicism toward the latter. Both attitude patterns are not necessarily a reflection of ideological or personal sympathy or acquiescence with the current power elites. In their examination of the degree and reasons of support among religious and ethnic minorities for authoritarian or semi-authoritarian governments in the Middle East, Ceren Belge and Emre Karakoç identify three cleavages that determine such support. ${ }^{24}$

23 Interviews with Archbishop Alexander and Archpriest Mefodii Efendiev, Baku, October 23, 2015; interviews and conversations with parish worker and mass attendants at three parishes in Baku, October 21-22, 2015.

24 Ceren Belge and Emre Karakoç, "Minorities in the Middle East: Ethnicity, Religion, and Support for Authoritarianism," Political Research Quarterly 68, no. 2 (2015): 282-283. 

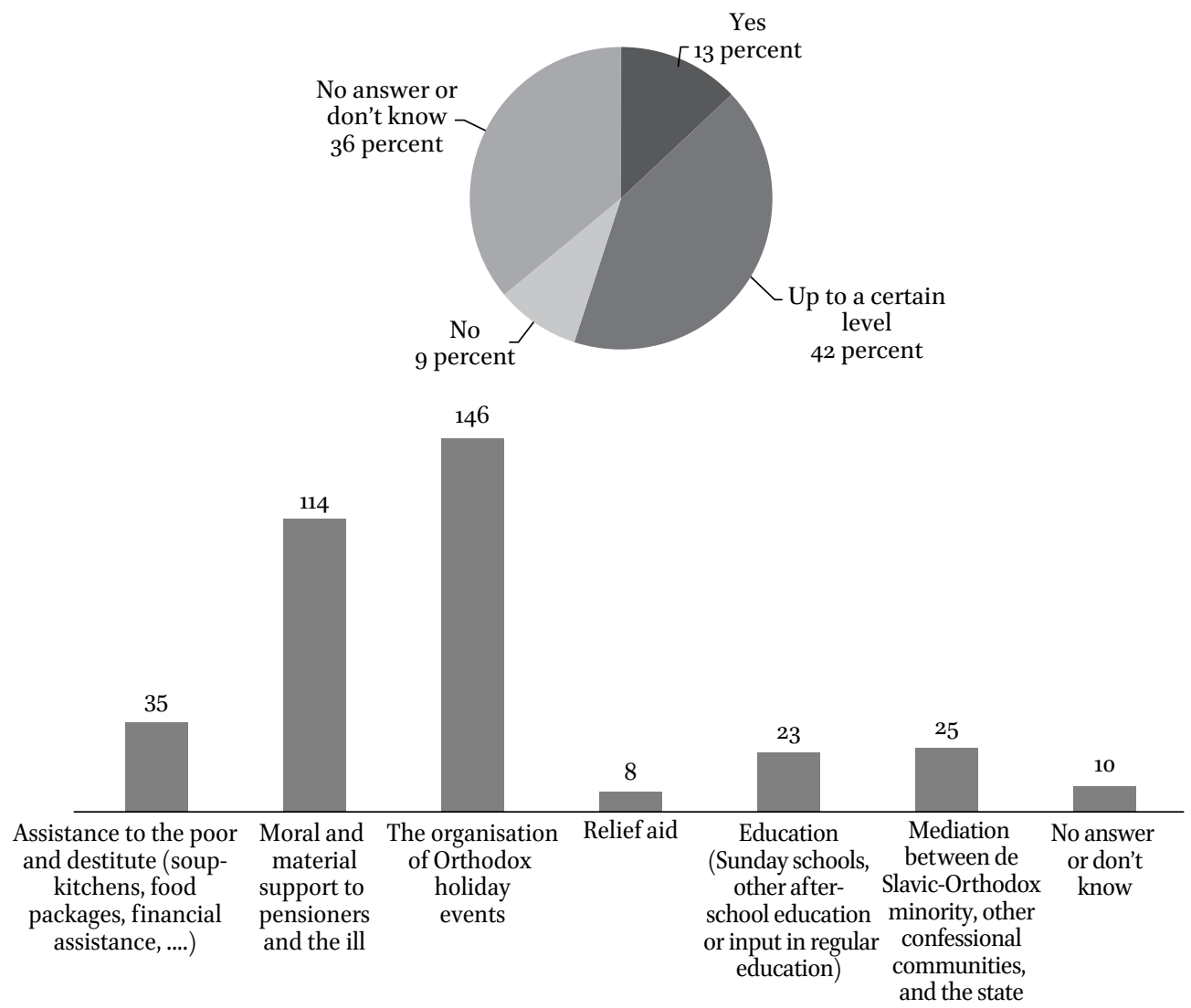

FIGURE 9 Perceived level of presence and activeness of the Orthodox Church, its clergy and lay parish workers in the social field (supra-in percent share), and the specific areas and activity where they are seen to be (infra-in number of respondents, more than one answer possible)

The first is social class, where minorities in states in which they are disproportionately represented among the wealthy will likely support the status quo. As has been seen earlier on, this is not the case here. The near-totality of the country's financial oligarchy and wealthier segments of society are Azerbaijani. The second cleavage is secular-religious. In cases where state-building has accentuated the secular-religious cleavage by eliminating, subordinating, or co-opting religious institutions in a highly religious society, democratization has different applications for differently situated minorities. Azerbaijan is rather a highly secularized society with increasing levels of religious observation among both the Shia and Sunni majority population. Contrary to what can be observed in Azerbaijani Shiism and Sunnism, Orthodoxy in the country 
has no real movement of independent priests and parishes who want to operate and practice independently from state-sanctioned religious authorities, which many perceive as being too connected with the current political regime. Some of the people of Orthodox background who are dissatisfied with the official clergy but who wish to remain practicing Christians may have joined the Protestant movements instead. In line with a policy established by the Moscow Patriarchate, the Baku eparchy tries to get the most out of cohabitation with Muslims, in order to confront Protestantism, Pentecostalism, and other sects and to fight against social ills associated with globalization. ${ }^{25}$

Finally, the third cleavage is ethnic. In societies ruled by an ethnic or ethnicconfessional minority, the status quo is advantageous; in states controlled by members of the ethnic majority, it is less clear-cut and depends on the status granted. The state is clearly dominated, if not owned, by the Azerbaijani majority, and the Orthodox Slavs no longer have the favored position of dominant minority they used to have in the Azerbaijani SSR. Neither do they have an autonomous district or other territory in the country. By a de facto arrangement, they - along with the Jewish minority - do have a representative in parliament who is a member of the presidential party. The Russian language, a crucial identity component, has been largely removed from both the official sphere and the public space - although scores of Russian loanwords continue to be used in both colloquial and official Azerbaijani - but it remains important as a lingua franca and idiom of education, especially in Baku and to a lesser extent Ganja. ${ }^{26}$

Azerbaijan's current power elites, shaped and partly Russianized as they were in the mold of the USSR and its policies of indigenization of the communist structures, are, however, seen to form some continuity with a UssR that nearly 63 percent of respondents in our survey have "very" or "rather" positive associations with. ${ }^{27}$ More importantly, there is a rather strong feeling among the population of interest, reinvigorated more recently by the psychological

25 Irène Semenoff-Tian-Chansky, "L'Église orthodoxe russe, un facteur politique à prendre au sérieux?," Politique étrangère 66, no. 1 (2001): 152-153.

26 According to the survey results, 53 percent of the respondents reported that they speak, write, and read Azerbaijani, the official majority language, "fluently" or "rather well" and 41.7 percent "in a limited way."

27 For a more in-depth examination of the formation of indigenous communist state elites, see the Azerbaijan-related examples in Olivier Roy, La nouvelle Asie centrale ou la fabrication des nations (Paris: Seuil, 1997), 141-162; Avioutskii, "Les clans en Azerbaïdjan." 
impact of the war in Donbass in southeastern Ukraine and by the horrors of the Syrian war, that for all its corruption and autocratic ills and excesses, the secularist regime and the stability that it is seen to ensure, at least leave room for the survival of an Orthodox Christian community in the country. The presence of an Orthodox community is also an important element in the Azerbaijani government's diplomacy with Russia, Belarus, and Serbia, and in its efforts to upkeep the image of a "land of tolerance" that the regime has promoted to the international community. ${ }^{28}$

\section{Which "Diaspora" Identity?}

Due to its size and population share, the Orthodox Slavic community in Azerbaijan represents a paradigm quite different from its counterparts in Kazakhstan and some of the Baltic countries, where people of the same background form as much as one-fifth of the population. In its present share, it is too small to form a real voting bloc or a base for an effective communalist political movement. It does have a social and cultural identity perceived to be definitely different from the country's majority population. And Orthodoxy occupies a rather important position in this identity. Figure 10 shows that, in the current conditions and despite its near-insignificant population share, the Orthodox community in Azerbaijan, especially in Baku where the critical mass of kinfolk and fellow parishioners remains much larger than in Ganja and especially the countryside, feels that it can somehow sufficiently preserve its individuality.

The Orthodox community exists in a space defined by a long historical presence in the country dating back generations, by the opportunities created during the years of economic growth in Azerbaijan, and by the modalities and conditions created by the official interpretation and practice of secularism and inter-ethnic and religious tolerance. As Figure 11 reflects, the main societal challenges and threats identified by the Orthodox, frequently based on personal experiences in everyday life, are pretty similar to those that generally come forward when one asks the same question to the Muslim Azerbaijani majority: unemployment, corruption, including economic monopolies, the state of health care and education, and, perhaps surprisingly to some, the occupation of Nagorno-Karabakh, especially because of the potential that this now-frozen war may flare up again.

28 For an example of how this is actively promoted at the UN Alliance of Civilizations, see http://www.unaoc.org/2013/og/from-land-of-fire-to-land-of-tolerance. 


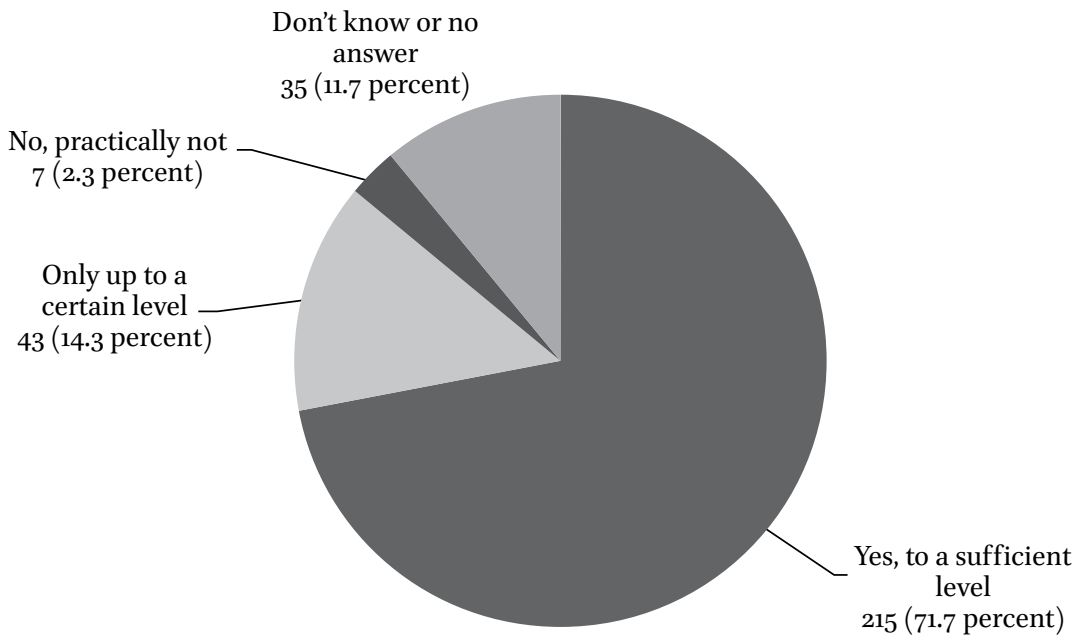

FIGURE 10 Can the Orthodox community preserve its ethnic and confessional identity in Azerbaijan? (in number of respondents and percent share)

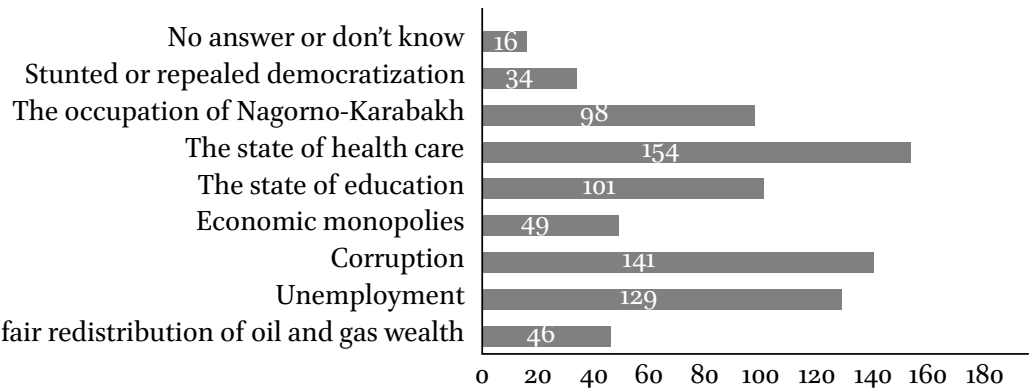

FIGURE 11 Main societal challenges and threats affecting Azerbaijani society as perceived by its Slavic Orthodox minority (in number of respondents, several answers possible)

There does not seems to be complete disengagement on this important issue in the national narrative of Azerbaijan. As a matter of fact, a view that came up several times during interviews and informal conversations in the Baku area was that Slavs have also been negatively affected by the NagornoKarabakh war, specifically the Molokan villages in the areas that were shelled and Stepanakert's small Slavic Orthodox population, which had to flee to Baku or Russia during the hostilities. Despite the assistance given by Russian units or at least certain individual commanders to Armenian separatists during the Nagorno-Karabakh war, only 2.6 percent of the Orthodox respondents felt that their community is perceived as pro-Armenian. A joint 65 percent of those questioned even have negative or very negative feelings vis-à-vis Armenia as a 
state, which leans toward the predominant opinion in Azerbaijani society. The sincere majority feeling here though, might lean more toward a neutral stance or indifference. But given the high sensitivity of the topic and given the minority paradigm, we might have a 'sociological trap' in which many respondents provided answers considered "safe" or socially desirable.

Orthodox and other traditional oriental Christian churches are not represented among Azerbaijan's Shia and Sunni Muslim majority per se, contrary to the activities of non-traditional Christian currents like Pentecostalism that also proselytize among Muslims, often half-underground or through front organizations such as book cafés and language courses. Also, the Orthodox and Slavs are not perceived to be particularly privileged nor to control certain sectors of the economy or economic monopolies. And the fact that there is no Slavic Orthodox concentration in a geographic area bordering Russia means that they are not considered potentially separatist or a threat to national unity, either. In line with Sébastien Peyrouse's observations on the other side of the Caspian, the main confessional cleavage in Azerbaijan lies elsewhere: between traditional and state-sanctioned Islam and Christianity on one hand, and nontraditional currents and practices like the independent Shia movements, Salafism, Protestantism, and Pentecostalism, on the other. ${ }^{29}$

In what diaspora identity do the Orthodox Slavs of Azerbaijan eventually fit, then? To answer this, we look into the typology in Table 2, which is based on the most useful model by Pål Kolstø. We enlarged this schematization with a number of historical and current examples to offer a basis for comparison. In the original model, Kolstø states that Slavic and culturally Orthodox diasporas may be confronted with a choice between three cultural identities: identification with the dominant culture in the external homeland; development of a new but basically Slavic self-understanding; and identification with the dominant culture in the state of residence. At the same time, politically, Kolstø proposes four options: loyalty toward the historical boundaries of the greater Russian state; loyalty toward the present and much-reduced Russian state; aspirations to create a new nation-state; and finally, loyalty toward the nationalizing state of residence. ${ }^{30}$

29 Sébastien Peyrouse, "Existe-t-il un ancrage spatial des minorités chrétiennes en Asie centrale? Le poids du passé russo-soviétique," Revue des mondes musulmans et de la Méditerranée, special thematic issue of Identités confessionelles et psychologiques en terres d'islam 107-110 (2005): 465-466.

3o Pål Kolstø, "The New Russian Diaspora-An Identity of Its Own? Possible Identity Trajectories for Russians in the Former Soviet Republics," Ethnic and Racial Studies 9, no. 3 (1996): 613-617. 
TABLE 2 Possible Slavic diaspora identities within the former USSR

\begin{tabular}{|c|c|c|c|}
\hline \multirow[t]{2}{*}{ Political loyalty } & \multicolumn{3}{|c|}{ Cultural self-understanding } \\
\hline & $\begin{array}{l}\text { External } \\
\text { homeland }\end{array}$ & $\begin{array}{l}\text { A new entity (virtual or } \\
\text { physical) }\end{array}$ & $\begin{array}{l}\text { Nationalizing state of } \\
\text { residence }\end{array}$ \\
\hline $\begin{array}{l}\text { Historical boundaries } \\
\text { (reconstitution of the } \\
\text { USSR) }\end{array}$ & $\begin{array}{l}\text { Traditional Soviet } \\
\text { (support for repub- } \\
\text { lican Communist } \\
\text { Parties) }\end{array}$ & $\begin{array}{l}\text { The "neo-Cossacks" with } \\
\text { maximum program (the } \\
\text { Kokchetau Cossacks in } \\
\text { 1995, the "Pugachev group" } \\
\text { in Ust-Kamenogorsk in } \\
\text { 1999, both in Kazakhstan) }\end{array}$ & $\begin{array}{l}\text { Support for republi- } \\
\text { can state elites issued } \\
\text { from the UssR and } \\
\text { the old Communist } \\
\text { Party apparatus. }\end{array}$ \\
\hline $\begin{array}{l}\text { External homeland } \\
\text { (the Russian } \\
\text { Federation) }\end{array}$ & $\begin{array}{l}\text { Irredentism (the } \\
\text { Crimean reattach- } \\
\text { ment, the Donbass } \\
\text { uprising) }\end{array}$ & $\begin{array}{l}\text { The "neo-Cossacks" with } \\
\text { minimal program (Cossacks } \\
\text { in Belarus and Azerbaijan), } \\
\text { the Slavic movement Lad } \\
\text { in northern Kazakhstan in } \\
\text { 1992-1997 }\end{array}$ & $\begin{array}{l}\text { Orientation toward } \\
\text { Russian media and } \\
\text { popular culture, } \\
\text { identification with } \\
\text { Orthodox Christianity } \\
\text { ("ethno-Christianity"). }\end{array}$ \\
\hline A new state of its own & - & $\begin{array}{l}\text { Transnistria, the Donetsk } \\
\text { and Lugansk republics in } \\
\text { eastern Ukraine }\end{array}$ & - \\
\hline $\begin{array}{l}\text { Nationalizing state of } \\
\text { residence }\end{array}$ & $\begin{array}{l}\text { Integrating na- } \\
\text { tional minority }\end{array}$ & - & $\begin{array}{l}\text { Assimilation or } \\
\text { co-optation }\end{array}$ \\
\hline
\end{tabular}

Source: Table created by Bruno De Cordier, on the basis of Pål Kolstø, "Beyond Russia, Becoming Local: Trajectories of Adaptation to the Fall of the Soviet Union among Ethnic Russians in the Former Soviet Republics," Journal of Eurasian Studies 2, no. 2 (2011): 158.

If one puts these options against the historical as well as current realities of the Orthodox in Azerbaijan, there is clearly no separatist tendency nor any movement to set up parallel institutions among the population of interest or certain groups or segments therein, nor aspirations to create a new nation-state. What there is can be situated on the intersection of nationalizing states of residence, identification with historical boundaries, and identification with an external homeland. This manifests itself in two ways. To start with the Soviet legacy, both the Azerbaijani majority and the Slavic minorities share an experience of nation-building under a system that privileged the ethnic-national over the confessional. The Slavic component was generally dominant or at least a 
long-dominant minority - "the majority of the minority" - at the level of the Azerbaijani SSR. ${ }^{31}$

This historical experience still causes the Orthodox to identify with a greater Russian space. Belonging to this space is defined, first of all, by the Russian language. Second, there are the predominantly positive to very positive memories of the USSR, prevalent among 63 percent of the respondents, either through direct personal experience, idealized memories, and inter-generational lore. Third, there are ties and interactions with relatives in Russia, which 45.3 percent of the interviewed reported having. And fourth, there is the influence of information channels from Russia, which 44 percent declared to be their primary source of information. Slightly over 90 percent have a very or rather positive view of Russia as a country and society and 64.7 percent strongly support a close association if not union among Azerbaijan, Russia, and Belarus. Orthodoxy here is a component of an ethnic identity that, in turn, reflects a cultural-social association with Russia or at least a Russian greater space rather than the existence of an Orthodox nation per se. ${ }^{32}$ This could change though; for example, if the erosion of ethnic identity through linguistic assimilation and intermarriage leads to a stronger emphasis, among part of the culturally Orthodox, on their confessional distinctiveness.

A portion of Baku's Slavic and culturally Orthodox community sees itself (as do much of the ethnically Azerbaijani urban intelligentsia) as bearers of a specific, long-standing Baku identity. This identity is, or was, first, perceived to be characterized by a strong multi-ethnicity, when the city was still inhabited by Slavs, Azerbaijani, a sizeable Armenian community, and an active Jewish minority. Until 1979, ethnic Azerbaijanis did not even constitute the majority of the city's population. As Bruce Grant observed, most visitors to the capital of the former Azerbaijani SsR were familiar with its cosmopolitanism and internationalism, which was often emphasized by its inhabitants. ${ }^{33}$ It was also seen to be characterized, in reality as well as idealized lore, by sophistication, a strong Russified intelligentsia and (relative) permissiveness in terms of culture and social mores.

31 See also Peyrouse, "Existe-t-il un ancrage spatial des minorités chrétiennes en Asie centrale?"

32 Kathy Rousselet, "L'Église orthodoxe russe et le territoire," Revue d'études comparatives Est-Ouest, special issue, La Russie: géographie des territoires (2007): 76-77.

33 Bruce Grant, "Cosmopolitan Baku," Ethnos 75, no. 2 (2010): 123. See also the different chapters and testimonies in Bakhram Bagirzade, Gorod moey molodosti (Baku: Şərq-Qərb, 2012). 
This identity is strongly felt to be lost since the departure of a large portion of the Slavs and most Armenians after 1988-1991 and since the arrival of Azerbaijanis displaced from Nagorno-Karabakh and, especially, of the masses of rural migrants from the provinces, to the extent that the titular nationality now forms go percent of the city's population. The gradual demolition of older residential quarters like the old Sovietskii area and Yasamal to make room for posh apartments and condos also adds to a feeling that the old, organic Baku identity is dying fast. Many claim that today the city's cosmopolitan and apparently tolerant character only remains in some parts of the city center like the old Baksoviet area and among the Russified intelligentsia. But for the rest, the korennye bakintsy ("native Bakuvians," to which many local Slavs feel to belong) who perceive themselves as distinct, well-educated, mannered people, and the rayonnye ("district folk," people that migrated to Baku from other parts of the country) now form separate worlds.

Although not mainstream Orthodox, the Molokans, a "minority within the minority," are generally considered to be part of the country's Slavic stratum both by the majority and by the mainstream Orthodox. Among the Azerbaijani majority, Molokans are generally viewed with a certain regard and appreciation, not only for being Russians, but also for their work ethic and wellorganized community. This view has created a certain attractiveness for the village of Ivanovka, which is both the Molokans' demographic center and home to the last collective farm in the country. As a result, the area has seen its population change over the last 15 years or so. One-third of the population there is now Azerbaijani. Nevertheless, the growing interest among Azerbaijani for Ivanovka is not met with the same enthusiasm by the Molokans themselves, who are uncertain about the future of their close-knit, endogamous, and agriculture-based community. ${ }^{34}$

\section{Conclusion}

The main existential threat to the Slavic population, and hence Orthodoxy, in the country today, is an aging ethnic-demographic base that is not going to be adequately replaced, especially outside of Baku, by either natural replacement or new followers. One of the factors that retains its acceptance by the majority culture, namely that it does not actively try to gain a following beyond its traditional Slavic community, thus stunts its future presence in the country. 
As for the Molokans, it remains to be seen whether the group can perpetuate its endogamous social order without compromising its identity.

Unless radical instances of historical breaking points occur, Orthodoxy will not disappear from Azerbaijan. Even if in the future, Islam, moreover Shiism, could, and likely will, play a stronger role in both society and governance, this should not be an impediment for the perpetuation of an Orthodox community in the country. But its base will unavoidably become more heterogeneous if it is to endure, not only consisting of the numerically smaller segments of younger Slavs, but also expatriate Russians, people of mixed origin or unclear ethnicconfessional identity - who might even become its most active adherents and advocates - and adherents of smaller, traditional-Christian groups that could be absorbed. In such circumstance, the Church and its Baku eparchy will likely build their legitimacy as bearers of a continuity of Christianity in the southern Caspian, which started with the Udi-Albanian Church and to which they already often refer in their discourse. 